\title{
STEROID HORMONE REQUIREMENTS FOR THE MAINTENANCE OF EARLY PREGNANCY IN SHEEP: A STUDY USING OVARIECTOMIZED ADRENALECTOMIZED EWES
}

\author{
I. A. GUMMING, R. BAXTER AND R. A. S. LAWSON \\ Department of Agriculture, S. S. Cameron Laboratory, \\ State Research Farm, Werribee, Victoria 3030, Australia
}

\section{(Received 15th November 1973)}

Embryonic development will proceed normally in ewes ovariectomized 4 days after ovulation if the animals are treated daily with progesterone (Bindon, 1971). Oestrogens are required for implantation to proceed in rats and mice (Nalbandov, 1971) but this requirement has not been established for sheep. While oestrogens of ovarian origin have been excluded as being necessary for the establishment of ovine pregnancy, it is possible that oestrogen production by the adrenals could supply any requirements at this time (McLaren, 1973).

Adrenalectomized ewes can be mated and become pregnant (Harrison, Heap \& Paterson, 1972) provided they are supplied with glucocorticoids and mineralocorticoids. Tilton, Hoffmann, Light \& Buchanan (1971) report that adrenalectomy did not not reduce mating activity, fertilization rate or conception rate.

Reliable estimates of oestrogen production by the adrenal have been difficult to achieve because of the very low secretion rates. Baird (1968) found approximately $1 \mathrm{ng}$ oestrone in each of three $50-\mathrm{ml}$ samples of adrenal venous blood but found virtually no oestradiol-17 $\beta$ although it is possible for oestradiol to be formed by reduction of oestrone. Conversion of progesterone to oestrogens is possible but this requires an aromatization reaction and the major sites for aromatization are removed by adrenalectomy plus ovariectomy. We have used the adrenalectomized ovariectomized ewe to investigate the possibility that oestrogens could have a function during early pregnancy in the ewe.

The experiment was conducted on the State Research Farm, Werribee, Victoria, using a flock of twenty mature Corriedale ewes (mean live weight, $47 \mathrm{~kg}$ ). All of the rams used in the flock were fitted with harnesses and crayons to facilitate the recording of oestrus. During October 1972, the right adrenal was removed from nine of the twenty ewes. In mid-January 1973, a vasectomized ram was placed with the flock and the ewes were checked daily for service marks throughout the next 4 months. All the ewes exhibited oestrous cycles of normal duration (range 16 to 21 days).

Early in May 1973, a fertile ram was placed with the ewes and the daily checks of oestrus were continued. The first day on which oestrus was recorded for each ewe was designated Day 0. On Day 2, the ewes were transferred to an 
animal house and fasted overnight. On Day 3, bilateral ovariectomy and removal of the left adrenal were performed under general anaesthesia (Fluothane, ICI) in all the ewes. There were thus two groups: Group A-nine ewes ovariectomized and bilaterally adrenalectomized; Group $\mathrm{O}$-eleven ewes ovariectomized and unilaterally adrenalectomized.

All of the ewes were injected intramuscularly with $10 \mathrm{mg}$ progesterone (Knoll Laboratories) immediately before ovariectomy and with procaine penicillin and dihydrostreptomycin (Streptopen Injection, Glaxo-Allenburys) immediately after surgery. The ewes of Group A were each injected with $20 \mathrm{mg}$ cortisone acetate (Ikapharm) immediately before removal of the left adrenal.

Table 1. Numbers of ovulations and surviving conceptuses in ewes bilaterally ovariectomized and unilaterally or bilaterally adrenalectomized

\begin{tabular}{|c|c|c|c|c|c|c|}
\hline \multirow{2}{*}{ Treatment } & \multirow{2}{*}{$\begin{array}{l}\text { Ewe } \\
\text { No. }\end{array}$} & \multirow{2}{*}{$\begin{array}{l}\text { Day of } \\
\text { hysterectomy } \\
\text { or } \\
\text { slaughter }\end{array}$} & \multirow{2}{*}{$\begin{array}{l}\text { No. of } \\
\text { ovulations } \\
(C L)\end{array}$} & \multirow{2}{*}{$\begin{array}{c}\text { No. of } \\
\text { conceptuses } \\
\text { present }\end{array}$} & \multicolumn{2}{|c|}{ Embryo measurements } \\
\hline & & & & & $\begin{array}{l}\text { Weight } \\
(\mathrm{g})\end{array}$ & $\begin{array}{l}\text { Crown-rump } \\
(\mathrm{cm})\end{array}$ \\
\hline \multirow[t]{2}{*}{$\begin{array}{l}\text { Group } O \\
\text { Ovariectomized and unilaterally } \\
\text { adrenalectomized after } \\
\text { conception }\end{array}$} & $\begin{array}{l}442 \\
454 \\
469 \\
623 \\
625 \\
649\end{array}$ & $\begin{array}{l}21 \\
21 \\
21 \\
21 \\
21 \\
21\end{array}$ & $\begin{array}{l}2 \\
1 \\
1 \\
1 \\
2 \\
2\end{array}$ & $\begin{array}{l}2 \\
1 \\
1 \\
\frac{2}{2}\end{array}$ & $\begin{array}{l}- \\
z \\
z\end{array}$ & $\begin{array}{c}0.53,0.60 \\
0.60 \\
0.60 \\
- \\
0.58,0.64 \\
0.65,0.70\end{array}$ \\
\hline & $\begin{array}{l}408 \\
445 \\
495 \\
540 \\
675\end{array}$ & $\begin{array}{l}35 \\
36 \\
35 \\
35 \\
35\end{array}$ & $\begin{array}{l}2 \\
2 \\
1 \\
1 \\
2\end{array}$ & $\frac{\overline{1}}{1 *}$ & $\begin{array}{l}\overline{2 \cdot 1} \\
\text { No embr } \\
\overline{1 \cdot 8}\end{array}$ & $\begin{array}{c}\overline{3.00} \\
\text { yo present } \\
\overline{2.90}\end{array}$ \\
\hline \multirow[t]{2}{*}{$\begin{array}{l}\text { Group A } \\
\text { Ovariectomized and bilaterally } \\
\text { adrenalectomized, one adrenal } \\
\text { having been removed before } \\
\text { conception }\end{array}$} & $\begin{array}{l}358 \\
507 \\
590 \\
712 \\
754\end{array}$ & $\begin{array}{l}21 \\
21 \\
21 \\
21 \\
22\end{array}$ & $\begin{array}{l}2 \\
1 \\
1 \\
2 \\
2\end{array}$ & $\frac{1}{1}+\frac{1}{1}$ & $\begin{array}{l}E \\
z \\
-\end{array}$ & $\begin{array}{l}0 \cdot 57 \\
0 \cdot 65 \\
0 \cdot 41 \\
\overline{0 \cdot 80}\end{array}$ \\
\hline & $\begin{array}{l}425 \\
457 \\
605 \\
670\end{array}$ & $\begin{array}{l}35 \\
35 \\
35 \\
35\end{array}$ & $\begin{array}{l}2 \\
2 \\
1 \\
1\end{array}$ & $\frac{2}{2}$ & $\begin{array}{c}1 \cdot 8,1 \cdot 9 \\
2 \cdot 0,2 \cdot 3 \\
\frac{2 \cdot 3}{}\end{array}$ & $\begin{array}{c}2 \cdot 61,2 \cdot 72 \\
2 \cdot 72,2 \cdot 78 \\
\frac{-}{3 \cdot 35}\end{array}$ \\
\hline
\end{tabular}

* The conceptus consisted of chorion (70 cm in length) and amnion $(0.9 \mathrm{~cm}$ in length). No cotyledonary development was evident.

$\uparrow$ Embryo dead; crown-rump length indicative of survival to about Day 19.

After surgery, ewes were returned to the animal house where they were individually penned and allowed free access to chopped lucerne hay. Beginning $12 \mathrm{hr}$ after surgery and thereafter every $12 \mathrm{hr}$, each ewe of Group A was injected intramuscularly with $10 \mathrm{mg}$ cortisone acetate, $2.5 \mathrm{mg}$ desoxycorticosterone acetate (Ikapharm), and 7.5 $\mathrm{mg}$ progesterone in arachis oil and the ewes of Group $\mathrm{O}$ received $7.5 \mathrm{mg}$ progesterone in arachis oil only.

On Days 21 to 22 and 35 to 36, six and five ewes, respectively, from Group $\mathrm{O}$ were hysterectomized under general anaesthesia while five and four ewes, respectively, from Group A were slaughtered and their uteri were removed. The uteri were incised and any conceptuses were removed for examination. 
Crown-rump lengths of embryos were measured and the heart beat was observed in fetuses from ewes on Days 21 and 22. Embryos of ewes slaughtered on Day 35 or 36 were weighed and crown-rump lengths were measured. Viability was assessed using these measurements and the gross visual appearance of embryos and associated membranes was recorded.

Of the seventeen ova shed by ewes in Group $\mathrm{O}$, ten were represented by viable embryos and a further one (from Ewe No. 495) by a trophoblastic vesicle lacking discernible embryonic remains (Table 1). Of the fourteen ova shed by ewes of Group A, eight were accounted for by viable embryos at slaughter. Eight of the eleven ewes of Group $\mathrm{O}$ were pregnant at hysterectomy and seven of the nine Group A ewes were pregnant at slaughter. There was no evidence to suggest any appreciable level of embryonic death between Days 21 to 22 and Days 35 to 36 (Table 1). Measurements of crown-rump length and of embryo weight did not reveal any indication of an effect of treatment on embryo development (Table 1).

There is now evidence for four waves of oestradiol secretion during the ovine oestrous cycle (Cox, Mattner \& Thorburn, 1971; Mattner \& Braden, 1972). Functional rôles for the later two surges in the non-pregnant ewe have been proposed by Caldwell, Tillson, Brock \& Speroff (1972) and Brown, Catt, Cumming, Goding, Kaltenbach \& Mole (1969). Braden \& Baker (1973) suggested that the second peak of oestradiol occurring about Days 6 to 9 might be necessary to prepare the uterus to receive the embryo at the time the zona pellucida was shed. This suggestion was not supported by our work and any function of maternal oestradiol to prepare the uterus must be fulfilled before Day 3; that is, while the embryo is still in the oviduct.

It would now appear that absolute levels of progesterone may be of greater importance in affecting embryo survival than minimum requirements for oestradiol. Gumming, Mole, Obst, Blockey, Winfield \& Goding (1971) have related a high plane of nutrition to low levels of progesterone and lowered embryo survival. Conversely, there is also evidence that high levels of endogenous progesterone are related to embryonic death (Cumming et al., 1971; Trounson $\&$ Moore, 1973).

The results of these experiments indicate that oestradiol from the maternal ovaries and adrenals is not required for successful maintenance of the sheep embryo between Days 3 and 36. It remains to be shown whether oestradiol of maternal origin secreted before Day 3 is involved in preparing the uterus for the embryo. In view of the demonstration by Perry, Heap \& Amoroso (1973) of the pig embryo's enzyme capacity to synthesize oestrogens from other steroids, there remains the possibility that embryonic oestradiol may play a rôle in the recognition of pregnancy and implantation.

\section{REFERENGES}

BaIRD, D. T. (1968) A method for the measurement of estrone and estradiol-17 $\beta$ in peripheral human blood and other biological fluids using $\left[{ }^{35}\right.$ S $]$ pipsyl chloride. F. clin. Endocr. 28, 244.

Bindon, B. M. (1971) The rôle of progesterone in implantation in the sheep. Aust. F. biol. Sci. 24, 149. Braden, A. W. H. \& Baker, A. A. (1973) Reproduction in sheep and cattle. In The Pastoral Industries of Australia, Chap. 9. Eds. G. Alexander and O. B. Williams. Sydney University Press. 
Brown, J. M., Gatt, K. J., Gumming, I. A., Goding, J. R., Kaltenbach, G. C. \& Mole, B. J. (1969) The release of luteinizing hormone in the ewe following oestradiol administration. F. Physiol., Lond. 201, 98P.

Galdwelil, B. V., Tillson, S. A., Brock, W. A. \& Sperofr, L. (1972) The effects of exogenous progesterone and oestradiol on prostaglandin F levels in ovariectomized ewes. Prostaglandins, 1, 217.

Gox, R. I., Mattner, P. E. \& Thorburn, G. D. (1971) Changes in ovarian secretion of oestradiol-17 around oestrus in the sheep. F. Endocr. 49, 345.

Gumming, I. A., Mole, B. J., Obst, J., Blockey, M. A. de B., Winfield, G. G. \& Goding, J. R. (1971) Increase in plasma progesterone caused by undernutrition during early pregnancy in the ewe. 7. Reprod. Fert. 24, 146.

Harrison, F. A., Heap, R. B. \& Paterson, J. Y. F. (1972) Pregnancy in adrenalectomized ewes; glucose production and steroid changes in late gestation. F. Physiol., Lond. 227, $21 \mathrm{P}$.

McLaren, A. (1973) Endocrinology of implantation. J. Reprod. Fert., Suppl. 18, 159.

Mattner, P. E. \& Braden, A. W. H. (1972) Secretion of oestradiol-17 $\beta$ by the ovine ovary during the luteal phase of the oestrous cycle in relation to ovulation. J. Reprod. Fert. 28, 136.

Nalbandov, A. V. (1971) Endocrine control of implantation. In The Biology of the Blastocyst, Chap. 22. Ed. R. J. Blandau. University of Ghicago Press.

Perry, J. S., Heap, R. B. \& Amoroso, E. G. (1973) Steroid hormone production by pig blastocysts. Nature, Lond. 245, 45.

Tilton, J. E., Hoffmann, R. H., Light, M. L. \& Buchanan, M. L. (1971) Adrenalectomy and embryonic survival in ewes. F. Anim. Sci. 33, 1163.

Trounson, A. O. \& MOORE, N. W. (1973) The effect of progesterone and oestrogen on the survival of fertilized ova in ovariectomized ewes. Proc. Aust. Soc. Endocr. 16, 32p. 